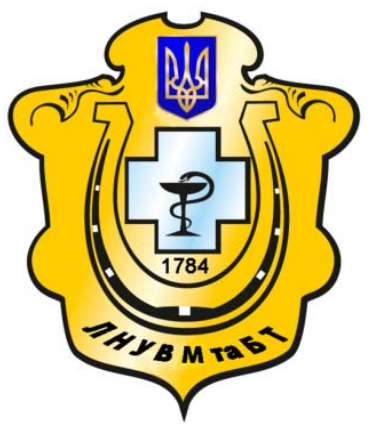

Науковий вісник Львівського національного університету ветеринарної медицини та біотехнологій імені С.З. Гжицького

Scientific Messenger of Lviv National University of Veterinary Medicine and Biotechnologies named after S.Z. Gzhytskyj

doi:10.15421/nvlvet7739

ISSN 2518-7554 print

ISSN 2518-1327 online

$\underline{\text { http://nvlvet.com.ua/ }}$

\title{
Порівняння бокового та медіанного доступу за оваріогістеректомії у кішок
}

\author{
О.Д. Степанов \\ Astepanov69@mail.ru \\ Подільський державний аграрно-технічний університет, \\ вул. Тараса Шевченка, 13, м. Кам'янеиь-Подільський, 32316, Украӥна
}

\begin{abstract}
В статті наведено результати досліджень, отриманих при застосуванні з метою оваріогістеректомії у кішок оперативних доступів через бокову та вентральну стінку живота. Дослідницька робота проводилася на здорових статевозрілих кішках. Операції виконувалися у верхній третині правої бокової черевної стінки та з застосуванням медіанного доступу. На боковій черевній стінці виконували косовертикальний розріз на межі пахвинної $і$ здухвинної ділянок у напрямку від переднього краю маклока до четвертого соска відповідного боку молочної залози. Вентральну черевну стінку розрізали $з$ використанням медіанної лапаротомії у позадупупковій ділянці. Встановлено, щчо при виконанні оваріогістеректомії у кішок із використанням запропонованого оперативного доступу через бокову черевну стінку тривалість операції і періоду загоєння відповідають таким же, як при застосуванні медіанної лапаротомії. Доведено, щьо оперативний доступ з поперечним розрізом у верхній третині правої бокової черевної стінки на межі пахвини і здухвини при оваріогістеректомії у кішок забезпечує кращі можливості для виконання оперативного прийому, ніж медіанний. Також відмічено, щуо при оваріогістеректомії у кішок оперативний доступ через верхню третину правої бокової черевної стінки з розрізом у напрямку від переднього краю маклока до четвертого соска відповідного боку молочної залози може бути рекомендований як альтернатива доступу через білу лінію живота.
\end{abstract}

Ключові слова: кішки, кастрачія, оваріогістеректомія, оперативний доступ, пахвина, здухвина, біла лінія, розріз, роги матки, яєчники.

\section{Сравнение бокового и вентрального доступа при овариогистерэктомии у кошек}

\author{
А.Д. Степанов \\ Astepanov69@mail.ru
}

Подольский государственный аграрно-технический университет, ул. Тараса Шевченко, 13, г. Каменец-Подольский, 32316, Украина

\begin{abstract}
В статье приведень результаты исследований, полученных при использовании с иелью овариогистерэктомии у кошек оперативных доступов через боковую и вентральную стенку живота. Исследовательская работа проводилась на здоровых половозрельхх кошках. Операчии выполнялись в верхней трети правой боковой брюшной стенки и с использованием медианного доступа. На боковой брюшной стенке выполняли косовертикальный разрез на стыке паховой и подвздошной области в направлении от переднего края маклока до четвертого соска соответствующей стороны молочной железы. Вентральную брюшную стенку разрезали с использованием медианной лапаротомии в позадипупочной области. Установлено, что при выполнении овариогистерэктомии у кошек с использованием предложенного оперативного доступа через боковую брюшную стенку продолжительность операции и периода заживления соответствуют таким же, как при использовании медианной лапаротомии. Доказано, что оперативный доступ с разрезом в верхней трети правой боковой брюшной стенки на стыке паха и подвздоха при овариогистерэктомии у кошек обеспечивает лучшие возможности для выполнения оперативного приема, чем медианный. Также отмечено, что при овариогистерэктомии у кошек оперативный доступ через
\end{abstract}

Citation:

Stepanov, A.D. (2017). Comparison of the flank and ventral access in case of the cat's ovariohysterectomy. Scientific Messenger LNUVMBT named after S.Z. Gzhytskyj, 19(77), 179-184. 
верхнюю треть правой боковой брюшной стенки с разрезом в направлении от переднего края маклока до четвертого соска соответствующей стороны молочной железы может быть рекомендован в качестве альтернативы доступа через белую линию живота.

Ключевые слова: кошки, кастрация, овариогистерэктомия, оперативный доступ, пах, подвздох, белая линия, разрез, рога матки, яичники.

\title{
Comparison of the flank and ventral access in case of the cat's ovariohysterectomy
}

\author{
A.D. Stepanov \\ Astepanov69@mail.ru \\ State Agrarian and Engeneering University in Podilya, \\ T. Shevchenko Str., 13, Kamyanets-Podilskyi 32316, Ukraine
}

\begin{abstract}
In the article results of examinations got in case of surgical accesses through the flank and ventral wall of the stomach's implementation on purpose to the cats' ovariohysterectomy are given.

The research work was carried out on healthy sexually-mature cats. Surgeries were done in the upper third of the right flank abdominal wall and in the behind the umbilical zone. The cross-cut on the boundary of groin and illium area in the direction from the hook-bone's front border to the fourth nipple of the mammary gland of the appropriate side was applied on the side abdominal wall. It is established that in case of the accomplishment of cat's ovariohysterectomy with the use of suggested surgical access through the side abdominal wall a duration of an operation and a period of healing are in line with those which are in case of application of median laparotomy.

It is proved that the surgical access with the cross-cut done in the upper third of the right flank abdominal wall and on the boundary of groin and illium area in case of cat's ovariohysterectomy secure better opportunities for the fulfillment of the surgical method than the median one. It is also noted that in case of cat's ovariohysterectomy the surgical access through the upper third of the right flank abdominal wall with the cut in the direction from the hook-bone's front border to the fourth nipple of the mammary gland of the appropriate side could be recommended as an alternative of an access through the middle line of the stomach.
\end{abstract}

Key words: cats, castration, ovariohysterectomy, surgical asses, groin, illium, middle line, cut, uterine horns, ovaries.

\section{Вступ}

Кастрація є незворотнім процесом, а тому іiї широко застосовують для контролю над чисельністю популяції собак та кішок (Howe, 2006).

Епідеміологи зацікавлені в контролі популяції бродячих і диких собак та кішок, оскільки вони є резервуарами зоонозних захворювань, таких як сказ і становлять загрозу для інших тварин і людей (Kutzler and Wood, 2006).

Популяція бродячих і диких собак та кішок, також викликає зацікавлення екологів, оскільки є загроза зникнення деяких видів через хижацьке знищення мільйонів птахів і ссавців у рік (Woods et al., 2003).

Крім репродуктивного контролю, оваріогістеректомія показана у випадках піометри, метриту, пухлин молочної залози і порушення репродуктивної функції. У кішок, крім описаних показань, ознаки тічки можуть негативно вплинути на відносини між твариною тп господарем і спонукати власника шукати спосіб контролю її розмноження (Goericke-Pesch, 2010).

Кастрацію кішки виконують 3 лапаротомією вентральної (Schebitz and Brass, 2007; Omeran et al., 2014) або бокової черевної стінки (McGrath et al., 2004; Burrow et al., 2006). Кожен з цих методів має переваги і недоліки, які накладають свій відбиток на їх застосування (Ehrhardt, 2012).

У кожному разі, при виконанні кастрації кішки вибір місця розрізу черевної стінки залежить від стану тварини і вміння лікаря (McGrath et al., 2004).

Разом $з$ тим, при виникненні критичної ситуації, іiі простіше вирішити, якщо розріз черевної стінки проведений по білій лініі, оскільки така техніка забезпе- чує кращий доступ до органів (Sympson and Ynhland, 2005).

Бокову черевну стінку розтинають 3 лівого (McGrath et al., 2004; Coe et al., 2006) або з правого боку тіла (Stepanov, 2015).

Використовують поперечний розріз на середині відстані від переднього краю маклока до останнього peбра (Ehrhardt, 2012). Також показаний розріз, який ведуть на відстані 2-4 см каудальніше останнього ребра, таким чином, щоб його дорсовентральний рівень був вершиною уявного рівностороннього трикутника, основою якого є лінія між гребенем здухвинної кістки і великим вертлом стегнової (Sympson and Ynhland, 2005).

Перевагами бокового доступу є те, що в досвідчених руках він дає змогу виконати оваріоектомію або оваріогістеректомію через дуже малий розріз, для закриття рани потрібно накласти лише кілька швів і дуже мала ймовірність зяяння рани (Hardie, 2007).

Разом $з$ тим, при виконанні оваріогістеректомії з боковим доступом досить важко дістати шийку матки, а це часто призводить до неповного видалення тканин матки і $\epsilon$ причиною подальшого розвитку пірометри іï кукси (Sympson and Ynhland, 2005).

При застосуванні бокового доступу тривалість проведення операції співставима 3 доступом через білу лінію живота (Coe et al., 2006).

За іншими даними - виконання оваріогістеректомії через здухвину потребує більше часу, ніж із застосуванням вентральної лапаротомії, що обумовлено складністю доступу через бокову черевну стінку (Oliveira et al., 2014). 
Для усунення вказаних недоліків, пов'язаних з доступом через бокову черевну стінку, при оваріогістеректомії у кішки нами був запропонований поперечний розріз у верхній третині правої бокової черевної стінки у напрямку від переднього краю маклока до четвертого соска молочної залози відповідного боку (Stepanov, 2015).

Метою проведених досліджень було дати порівняльну оцінку двох способів виконання оваріогістеректомії у кішок: через праву бокову черевну стінку та білу лінію живота.

\section{Матеріал та методи досліджень}

Робота виконувалася на клініці факультету ветеринарної медицини Подільського державного аграрно-технічного університету. Яєчники видаляли у здорових кішок віком понад 12 місяців. Всього було виконано десять кастрацій через розріз по білій лінії живота та десять в ділянці правої бокової черевної стінки на межі пахвини і здухвини.

Ввечері напередодні операції, а також зранку перед кастрацією кішку не годували. Як наркоз застосо- вували комбінацію ксилазину і золетилу. При проведенні медіанної лапаротомії тварину фіксували в спинному положенні, якщо операцію виконували через бокову черевну стінку - в лівому боковому положенні з відведеними назад тазовими кінцівками.

При проведенні оваріогістеректомії у кішок із застосуванням медіанної лапаротомії в позадупупковій ділянці операцію виконували звичайним способом (Coe et al., 2006).

Виконуючи операцію через праву бокову черевну стінку, розріз вели в ії верхній третині на межі між пахвинною і здухвинною ділянками вздовж лінії від переднього краю маклока до четвертого соска відповідної сторони молочної залози (рис. 1).

Після цього ділянку розрізу ножицями звільняли від підшкірного жиру, в результаті чого в рані оголювався зовнішній косий черевний м'яз. За допомогою малого гемостатичного пінцета 3 тонкими губками у центрі рани обережно проколювали черевні м'язи разом $з$ очеревиною. Розведенням браншів затискача збільшували отвір у черевну порожнину (рис. 2).

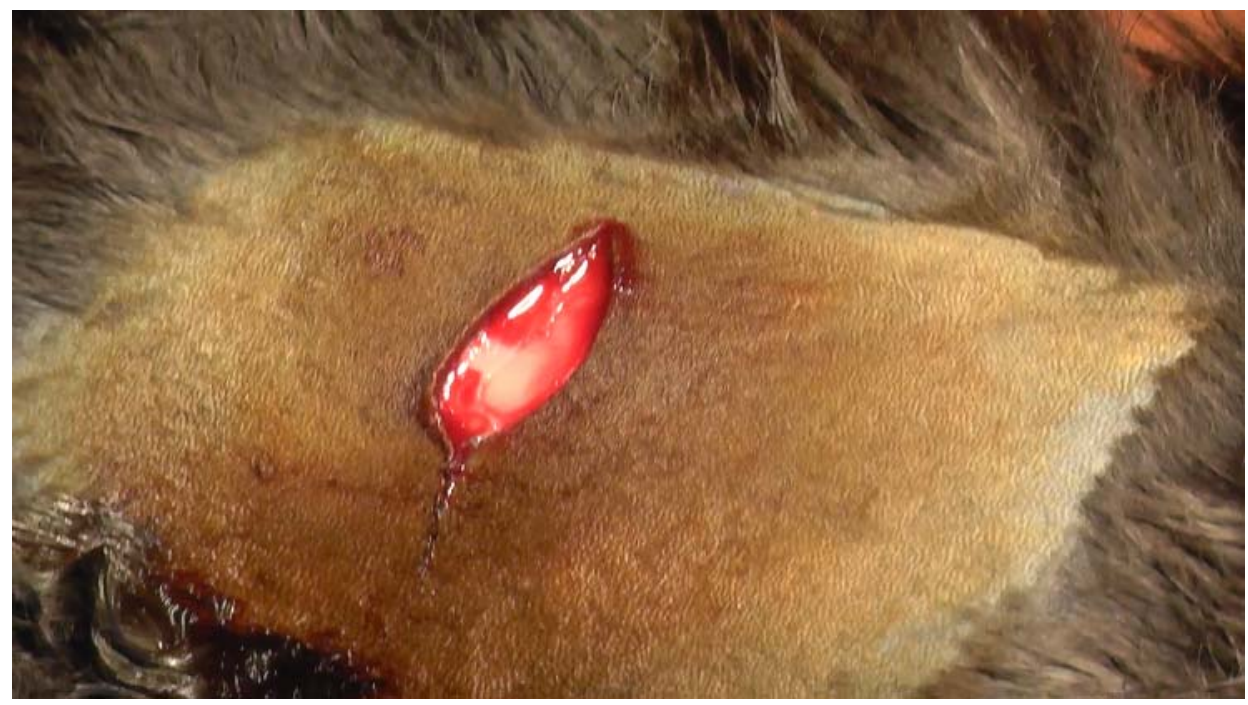

Рис. 1. Розріз шкіри

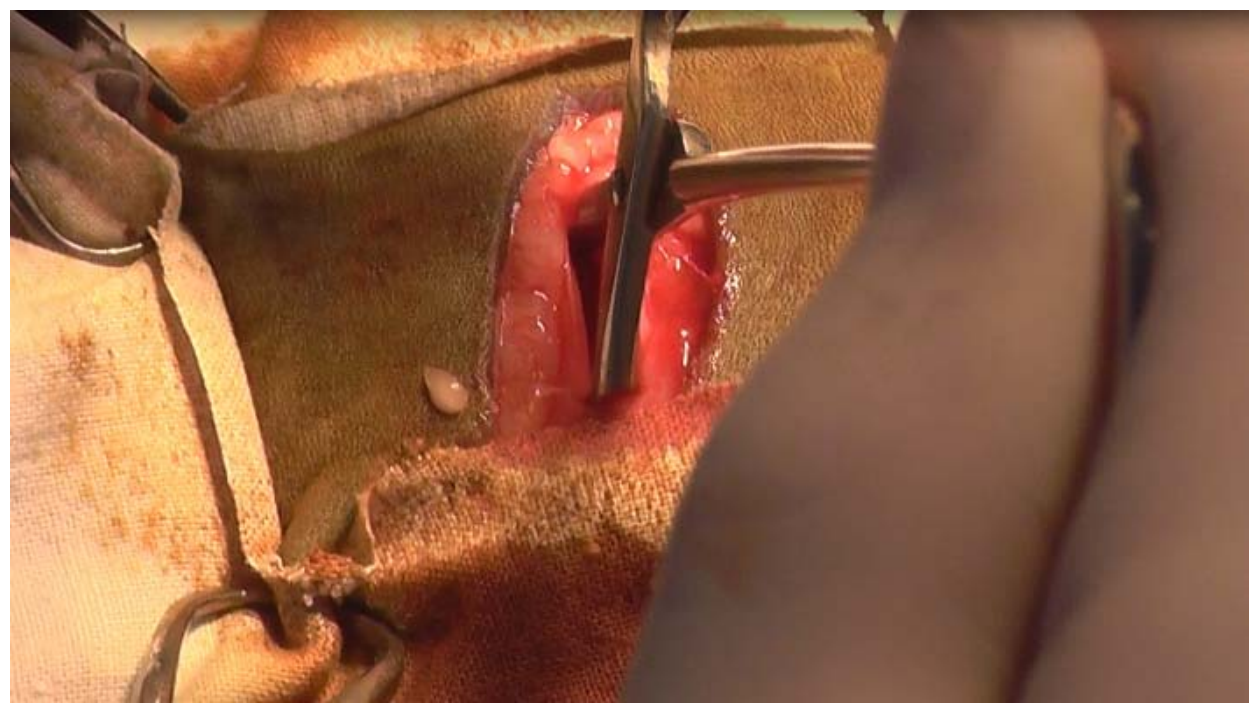

Рис. 2. Роз'сднання черевної стінки тупим способом 
У рану вводили кастраційний гачок або палець, яким захоплювали і підтягували назовні правий яєчник або ріг матки. Після видалення яєчників і частини тіла матки накладали по два стібки вузлового шва на внутрішній та зовнішній косий черевний м'яз, а також кілька вузлових стібків на шкіру.

\section{Результати та їх обговорення}

При виконанні оваріогістеректомії у кішок із застосуванням медіанної лапаротомії розріз шкіри починали на відстані 1 см від пупка і продовжували каудально на довжину 4,12 $\pm 0,22$ см. Середня тривалість кастрацій складала: $28,1 \pm 3,5$ хв.

Всі операції були виконані успішно, проте ми спостерігали деякі труднощі: виявлення яєчників у кішок, які ще не родили, вимагало додаткового часу.

В післяопераційному періоді у всіх прооперованих через розріз по білій лінії живота кішок рани загоювалися без ускладнень. Рановий шов утворювався за
7,2 \pm 0,7 діб. Загальний стан тварин впродовж перших п’яти діб після операції характеризувався пригніченням, вони переважно лежали. А в перші дві-три доби майже нічого не їли. Такі фізіологічні показники організму, як температура тіла, пульс, частота дихальних рухів не виходили за межі норми.

Виконуючи лапаротомію в ділянці правої бокової черевної стінки, в її верхній третині вели косовертикальний розріз шкіри завдовжки $3,18 \pm 0,16$ см. Операції тривали в середньому $25,2 \pm 2,8$ хв.

Характерною особливістю операцій було досить легке виконання лапаротомії, відшуковування рогів матки і закриття рани черевної стінки.

Також при використанні доступу через бокову черевну стінку положення рани забезпечувало сприятливі умови для накладання лігатур на яєчникову зв’язку на достатній віддалі від яєчника. При цьому не було необхідності попереднього роз'єднання підтримуючої зв'язки (рис. 3).

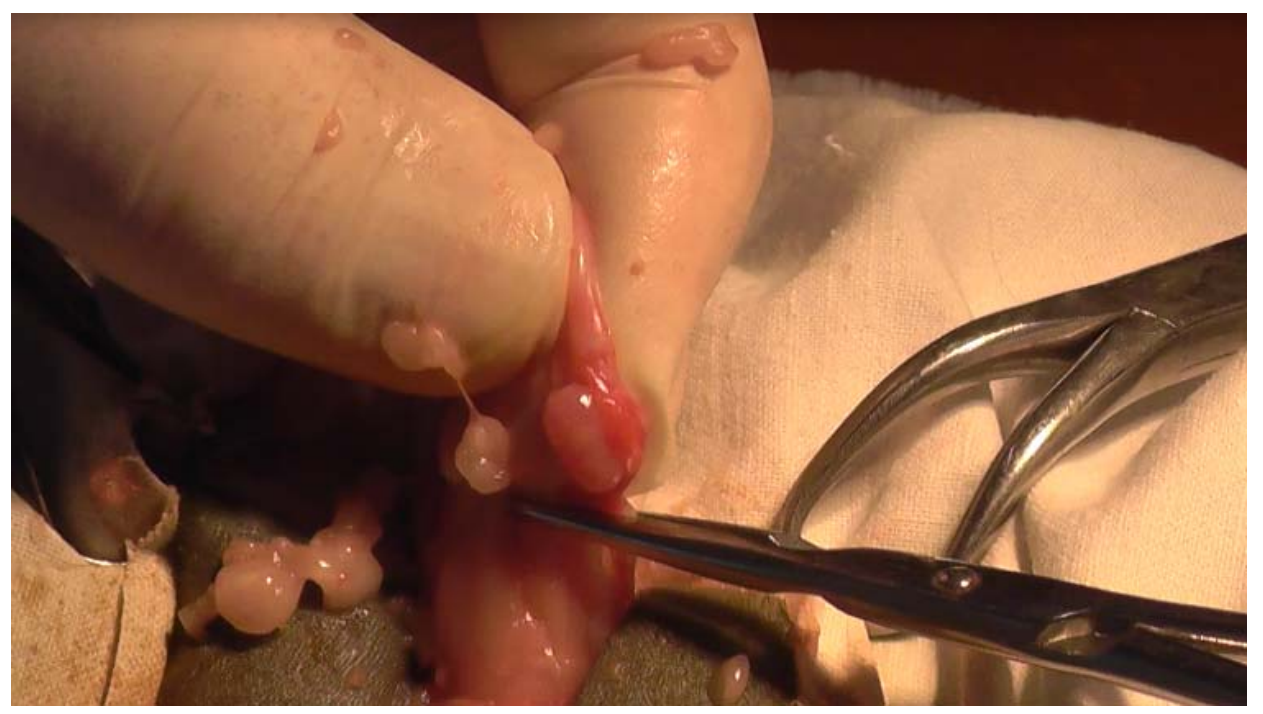

Рис. 3. Накладання затискача на ясчникову зв'язку

У зв'язку зі зручним розташуванням ранового отвору такий важливий етап операції, як виведення лівого яєчника, виконували без ускладнень. 3 цією метою у рану підтягували біфуркацію рогів матки i переходили на лівий ріг. Подібним чином було досить зручно накладати лігатури на матку. Це не вимагало збільшення розміру рани. При легкому натягуванні матки проводили прошивну лігатуру в ділянці ії̈ шийки (рис. 4).

Починаючи 3 другої доби після кастрації тварини приймали їжу, а через три доби їх стан майже не відрізнявся від доопераційного. У всіх прооперованих рани загоювалися без ускладнень, за 6,3 $\pm 1,8$ діб.

Згідно з отриманими даними, при застосуванні латерального доступу розмір рани менший, ніж після медіанної лапаротомії (P < 0,05). Це, очевидно, пов'язано з тим, що у випадку оперування через бокову черевну стінку збільшення розміру рани ніяк не впливає на проведення операції, тимчасом як при вентральному доступі це значно полегшує оперування.
Аналізуючи отримані дані стосовно тривалості проведення операції залежно від доступу, можемо констатувати, що використана нами техніка роз'єднання черевної стінки при боковому доступі $\epsilon$ ефективною. Разом із дещо меншими витратами часу на зашивання черевної стінки при латеральній лапаротомії це зменшує тривалість всієї операції.

Проте варто відмітити, що на перебіг операції впливають такі показники, як кваліфікація і досвід лікаря, його особисті переваги у використанні тієї чи іншої хірургічної техніки.

Стосовно легшого виявлення яєчників і матки при боковому доступі порівняно 3 медіанним можемо зазначити, що після латеральної лапаротомії і зміщення сальника матка перебуває під розрізом, тоді як після медіанної лапаротомії iї вкриває кишечник. Подібні дані були також отримані іншими дослідниками (Oliveira et al., 2014). 


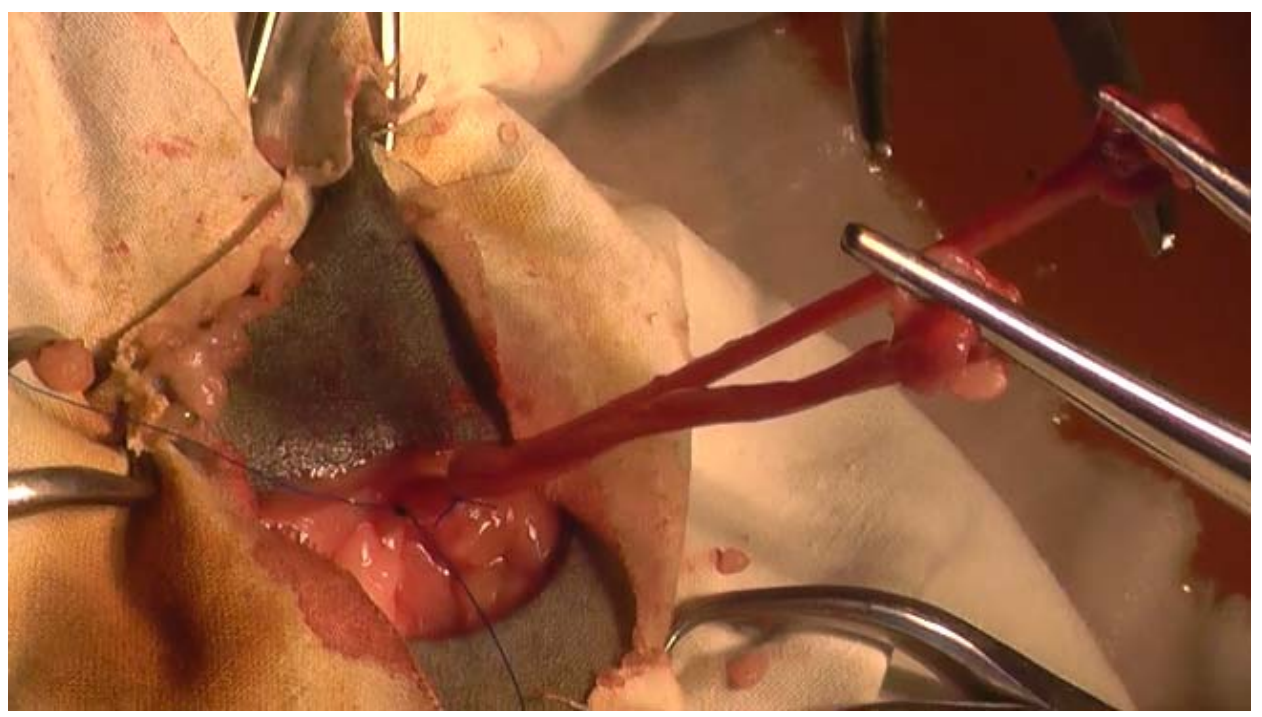

Рис. 4. Накладання лігатури на шийку матки

Кращі умови для накладання лігатур на яєчникові зв'язки і матку при оперуванні через бокову черевну стінку, на нашу думку, пов'язані зі зручним розташуванням запропонованого нами доступу. Як свідчить наш досвід (Stepanov, 2015), оваріогістеректомію у кішки можна виконати через косий розріз у пахвині, а також шляхом розрізу здухвини. Проте у першому випадку незручно накладати лігатури на яєчникові зв'язки, а в другому - неможливо дістатися шийки матки. Положення ж розрізу на межі пахвини і здухвини $\epsilon$ оптимальним для виконання оперативного прийому.

Згідно 3 отриманими нами даними, розміщення рани на боковій або вентральній черевній стінці створює сприятливі умови для іï загоєння. При цьому в разі бокового доступу, тварина у перші дні після операції, перебуваючи в лежачому положенні, має менше можливостей ушкодити рану.

Таким чином, як показали проведені дослідження, при порівнянні двох способів виконання оваріогістеректомії у кішок вірогідної різниці за тривалістю операції а також періоду загоєння рани не виявлено. Разом 3 тим, відмічено, що кожен $з$ них має певні особливості.

Згідно з отриманими даними, відносно важче виконувати лапаротомію та зашивати рану черевної стінки при оваріогістеректомії з доступом через білу лінію живота.

Також встановлено, що при меншому розмірі рани $(\mathrm{P}<0,05)$ оперативний доступ у верхній третині правої бокової черевної стінки на межі між здухвиною і пахвиною забезпечує кращі можливості для накладання лігатур на яєчникові зв'язки та матку, ніж медіанний.

Отримані дані дають змогу рекомендувати при виконанні оваріогістеректомії у кішок запропонований правобічний доступ на межі пахвини і здухвини як альтернативу традиційному медіанному.

\section{Висновки}

При порівнянні двох способів виконання оваріогістеректомії у кішок через вентральну і бокову черевну стінку не виявлено вірогідної різниці за тривалістю операції та періоду загоєння рани.

При оваріогістеректомії у кішок оперативний доступ з розрізом у верхній третині правої бокової черевної стінки у напрямку від переднього краю маклока до четвертого соска відповідного боку молочної залози забезпечує кращі можливості для виконання оперативного прийому, ніж медіанний.

При оваріогістеректомії у кішок оперативний доступ через верхню третину правої бокової черевної стінки 3 розрізом у напрямку від переднього краю маклока до четвертого соска відповідного боку молочної залози може бути рекомендований як альтернатива доступу через білу лінію живота.

Перспективи подальших досліджень. Проведена робота відкриває можливості для дослідження впливу різних способів виконання оваріогістеректомії у кішок на показники фізіологічного стану їх організму. Це дасть змогу визначити найбільш оптимальний 3 них не лише 3 точки зору техніки виконання, а й у зв’язку з впливом на організм тварини.

\section{Бібліографічні посилання}

Howe, L.M. (2006). Surgical methods of contraception and sterilization. Theriogenology. 66, 500-509.

Kutzler, M., Wood, A. (2006). Non-surgical methods of contraception and sterilization. Theriogenology. 66, 514-525.

Woods, M., McDonald, R.A., Harris, S. (2003). Predation of wildlife by domestic cats Felis catus in Great Britain. Mammal review. 33, 174-188.

Goericke-Pesch, S. (2010). Reproduction control in cats: new developments in non-surgical methods. J. Feline Med. Surg. 12(7), 539-546.

Omeran, B.M., Abdel-Wahed, R.E., El-Kammar, M.H., Abu-Ahmed, H. (2014). Ovariectomy Versus Ovariohysterectomy for Elective Sterilization of 
Female Cats. Alexandria Journal of Veterinary Sciences. 43(1), 73-81.

Schebitz, H., Brass, W. (2007). Ovar und Uterus. Operationen an Hund und Katze. Berlin, Germany: Parey, 273-274.

McGrath, H., Hardie, R.J., Davis, E. (2004). Lateral flank approach for ovariohysterectomy in small animals. Compend. Contin. Educ. Small. Anim. Pract. 26, 922930.

Burrow, R., Wawra, E., Pinchbeck, G., Senior, M., Dugdale, A. (2006). Prospective evaluation of postoperative pain in cats undergoing ovariohysterectomy by a midline or flank approach. Vet. Rec. 158(19), 657-660.

Ehrhardt, E.E. (2012). Performing an ovariectomy in dogs and cats. Veterinary Medicine. 107(6), 272.

Sympson, Dzh., Ynhland, H. (2005). Rukovodstvo po reproduktsyy y neonatolohyy sobak y koshek. M: Yzdatelstvo Sofyon (in Russian).

Coe, R.J., Grint, N.J., Tivers, M.S. (2006). Comparison of flank and midline approaches to the ovariohysterectomy of cats. Vet. Rec. 159, 309-313.
Stepanov, O.D. (2015). Vyznachennia operatyvnoho dostupu pry kastratsii kishok cherez bokovyi rozriz. Naukovyi visnyk LNUVMBT im. S.Z. Hzhytskoho. 17, 1(61), 1, 185-190 (in Ukrainian).

Stepanov, O.D. (2015). Vyznachennia operatyvnoho dostupu pry ovarioektomii kishok cherez bik. Naukovyi visnyk LNUVMBT im. S.Z. Hzhytskoho. 17, 2(62), 210-216 (in Ukrainian).

Hardie, E. (2007). Pros and Cons of Neutering International Veterinary Information Service /Electronic resource/ Ithaca NY (www.ivis.org), Mode of access: http://prdup102.ynet.co.il/ForumFiles 2/23999370.pdf. - Last access: 21-Oct-2007. - Title from the screen.

Oliveira, J.P., Mencalha, R., Sousa, C.A., AbiduFigueiredo, M., Jorge, S.F. (2014). Pain assessment in cats undergoing ovariohysterectomy by midline or lateral celiotomy through use of a previously validated multidimensional composite pain scale. Acta Cirúrgica Brasileira. 29(10), 633-638

Стаття надійшла до редакиії 24.03.2017 